\title{
External Qigong Therapy
}

National Cancer Institute

\section{Source}

National Cancer Institute. External Qigong Therapy. NCI Thesaurus. Code C154263.

A form of traditional Chinese energy therapy that involves the use of hand movements, acupressure, focused attention, and other mind healing techniques to direct the therapist's emitted Qi into a patient to regulate the patient's Qi activity. 